\title{
OLS 可視・熱赤外画像に見られる漁船の分布と海面温度の関係
}

\section{Relationship between the fishing fleet lights and SST distribution observed by OLS visible/infrared imagery}

\author{
伊藤 涼* ·長 幸平* ・下田陽久*・坂田俊文* \\ Ryo ITO, Kohei CHO, Haruhisa SHIMODA and Toshibumi SAKATA
}

\begin{abstract}
The OLS (Operational Linescan System) sensor on board the DMSP (Defense Meteorological Satellite Program) can observe the lights in the night. A nighttime OLS visible-near infrared (VNIR) channel image was overlaid on the simultaneously corrected OLS thermal infrared (TIR) channel image for the area around Japan. The OLS composite image showed a clear relationship between the location of fishing fleet lights detected by the VNIR channel and the sea surface temperature (SST) distribution observed by the TIR channel. Many fishing fleets were located at the cold side of boundary area of warm current and cold current. Since some types of fishes are likely to gather in certain sea temperature zones, the OLS composite image may provide useful information for the fishing fleets monitoring as well as for the marine resources management.
\end{abstract}

\section{1.はじめに}

200 海里時代を迎え，国際的な規模での漁業・海洋資 源の管理と合法的な操業が必要となり，的確な漁海況 情報の収集が国際的にも求められている。我が国では, 国内の漁船の操業状況については，各船舶からの報告 が義務づけられているが，外国渙船に関する情報は立 分とは言えずその操業状況の把握が急務となってい る。

米国の軍事気象衛星 DMSP (Defense Meteorological Satellite Program) に搭載された OLS (Optical Linescan System) センサは夜間の光の分布を観測す るセンサとして知られている。スルメイカ漁, サンマ 漁等では夜間漁船に照明を点灯し漁を行っており， OLSを用いることによりこうした漁船の光の分布を 検知することができる。また，魚は，漁種により定まっ た水温範囲で生活しており，良い漁場となる潮境，暖

\footnotetext{
*東海大学情報技術センター

Tokai University Research and Information Center テ151-0063 渋谷区富ヶ谷2-28-4

2-28-4, Tomigaya, Shibuya-ku, Tokyo, JAPAN

「写真測量とリモートセンシング」VOL. 37，NO. 4， 1998

冷水の渦が海面温度分布から推定できることが知られ

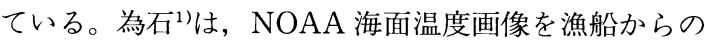
操業報告と対応させることにより，マイワシ群が沖合 いから沿岸水域への移動に暖水ストリ一マを利用し， そこに漁場が形成されるメカニズムを明らかにした。 また，アカイカ，スルメイカの漁場分布は，暖水渦の 変動抢よび形成が密接に関係していることも過去に報

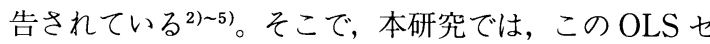
ンサの可視チャンネルが捉えた漁船の明かりの分布と 同時に観測されたOLS 熱赤外チャンネルが捉えた海 面温度分布の関係を解析し漁海況情報としての OLS データの有効性を検証した。

\section{DMSP/OLS の概要}

DMSP は地上 $833 \mathrm{~km}$ を約101分で周回する太陽同 期の極軌道衛星で気象衛星 NOAA 衛星と類似の軌道 を描く。1 機の衛星は 1 日 2 回地球上の同一地点を通 過する。DMSP は米国空軍により，常時 2 機の運用体 制がサポートされており，1 日4 回同一地点の観測が 可能となる。現在は F12, F13及びF14の 3 機が運用さ れている。DMSP は全球的な雲の分布の観測を主目的 とした OLS やマイクロ波放射計 SSM/I 等，表 1 に示 した6つのセンサを搭載している。 
表 1 DMSP の仕様

\begin{tabular}{|c|c|}
\hline 軌 道 & 太陽同期極軌道 \\
\hline 高＜wide>度 & $833 \mathrm{~km}$ \\
\hline 周 期 & 101分（14.1周/日） \\
\hline 軌 道 傾 斜 角 & $98.8^{\circ}$ \\
\hline 死 角 & 極点の周囲 $2.4^{\circ}$ \\
\hline デー夕送信速度 & 1.024Mbit/秒 \\
\hline 送 信 周 波 数 & $\begin{array}{l}2252.5 \mathrm{MHz} \\
226 \mathrm{MHz}\end{array}$ \\
\hline 搭 載 セン サ & $\begin{array}{l}\text { OLS（可視熱外センサ） } \\
\mathrm{SSM} / \mathrm{I} \text { （特殊マイクロ波センサ/イメージャー） } \\
\mathrm{SSM} / \mathrm{T} \text { （特殊マイクロ波センサ/温度） } \\
\mathrm{SSMT} / 2 \text { (特殊マイクロ波センサ/湿度） } \\
\mathrm{SSJ} / 4 \\
\mathrm{SSIES}\end{array}$ \\
\hline そ の 他 & $\begin{array}{l}\text { 米国空軍が管理 } \\
\text { 常時 } 2 \text { 機の稼働をサポート }\end{array}$ \\
\hline
\end{tabular}

表 2 OLS の仕様

\begin{tabular}{|c|c|c|c|c|c|}
\hline \multirow{2}{*}{ チャンネル } & \multirow{2}{*}{ 波 長 带 } & \multicolumn{2}{|c|}{ 分 解 能 } & \multirow{2}{*}{ 観測幅 } & \multirow{2}{*}{ データ長 } \\
\cline { 3 - 4 } & & fine & smooth & & \\
\hline 可視チャンネル (昼間用) & $0.40-1.10 \mu \mathrm{m}$ & $0.55 \mathrm{Km}$ & $2.7 \mathrm{Km}$ & & $6 \mathrm{bit}$ \\
\hline 可視チャンネル (夜間用) & $0.47-0.95 \mu \mathrm{m}$ & - & $2.7 \mathrm{Km}$ & \multirow{3}{*}{$3000 \mathrm{Km}$} & $6 \mathrm{bit}$ \\
\hline 熱赤外チャンネル & $10.0-13.4 \mu \mathrm{m}$ & $0.55 \mathrm{Km}$ & $2.7 \mathrm{Km}$ & & $8 \mathrm{bit}$ \\
\end{tabular}

OLS は約 $3,000 \mathrm{~km} の$ 観測幅を持つ，可視·熱赤外セ ンサである (表 2 参照)。OLSの可視チャンネル (正確 には可視近赤外チャンネル VNIR）は，昼間用と夜間 用とがあり，両者を切り替えて使う。昼間用の可視チャ ンネルは, 分解能が $0.55 \mathrm{~km}$, センサ感度が $10^{-3} \sim 10^{-5}$ $\mathrm{Watts} / \mathrm{m}^{2} \mathrm{strad}$ である。一方, 夜間用の可視チャンネ ルは分解能が $2.7 \mathrm{~km}$ ，センサ感度が，10 $10^{-5} \sim 10^{-9}$ Watts $/ \mathrm{m}^{2}$ strad である。それぞれ64階調で記録され る。また，熱赤外チャンネル(TIR)の分解能は，昼夜 を問わず $0.55 \mathrm{~km}$ で, $190 \mathrm{~K}^{\circ} \sim 310 \mathrm{~K}^{\circ}$ の範囲を256階調で 記録される。また, 分解能 $0.55 \mathrm{~km} の$ の゙ー夕を高分解能 モード (fine-mode) データと呼び，それを平均化して 実効的な分解能を $2.7 \mathrm{~km}$ としたもの, 及び夜間の可視 デー夕（分解能 $2.7 \mathrm{~km}$ ）を低分解能モード（smooth -mode) データと呼ぶ。OLS センサの夜間可視画像は, 都市の明かり, オーロラ, 焼畑の火などを捉えるユニ一 クな画像として知られている6778)。OLSデータは,
NOAA National Geophysical Data Center (NGDC) が，デー夕配布のサービスを行っている。OLSデー夕 は1979年から写真による配布が行われてきたが, 1992 年 9 月 8 日からはデジタルデー夕による配布も行われ るようになった。

\section{3. 解析対象領域・解析対象データ}

解析対象領域は, 図 1 に示した日本周辺の東経 $130^{\circ}$ $\sim 145^{\circ}$, 北緯 $30^{\circ} \sim 45^{\circ}$ の範囲である。この領域は, 黒潮 の分流と親潮の潮境や，対馬海流と東シ十海流の潮境 が形成される海域を含み, 漁獲量が多く, 海洋生物資 源の管理の観点からも重要な領域である。衛星デー夕 は1992年11月14日観測の OLS データおよびNOAA/ AVHRR データを使用した。この時期はスルメイカの 南下時期にあたり, OLS 可視データからは漁船の分布 を多数確認することができる。 


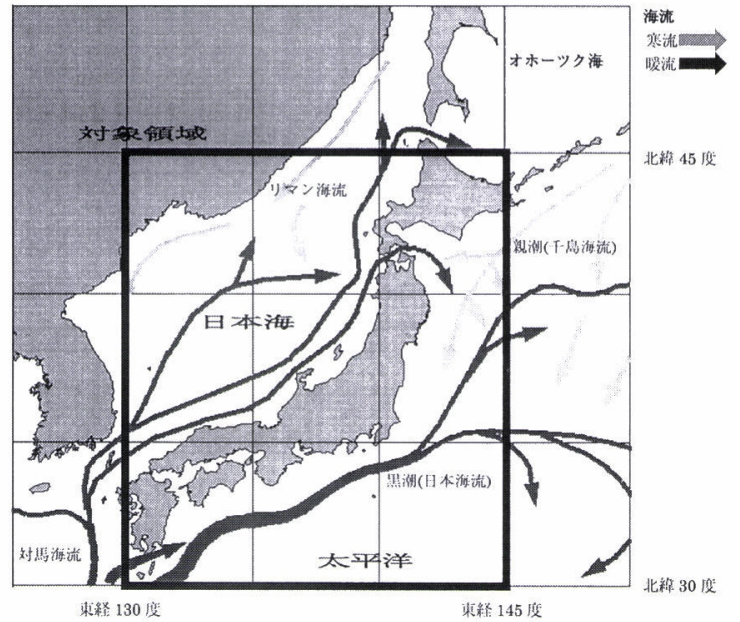

図 1 対象領域 ${ }^{11) 12)}$

\section{4. 解析手法}

本研究では，夜間に観測された OLS/VNIR データ から抽出した漁船の分布情報を海面温度分布, 200 海里 漁業水域情報等と統合することによって OLSデータ による漁海況情報抽出の有効性の検討を行った。

\subsection{OLS 可視データからの光の分布域の抽出}

まず，1周回分の OLS デー夕から対象である日本 周辺の領域を抽出し，地上基準点を用いて等緯経度座 標に変換した。画素サイズはNOAA/AVHRRデータ と同じ $1.1 \mathrm{~km}$ とした。

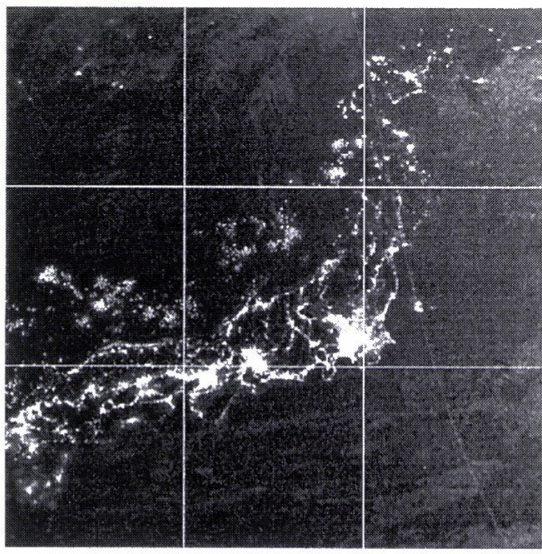

(a) 2 值化前
OLS/VNIR データは, 光の明るいところを強調し, 漁船の光の分布を確認しやすくするための 2 值化処理 を行った。しきい值を31とし，31以下を0に，それ以 上の值は 1 とした。しきい值は漁船の光の中心点が消 えない值で，雲などの反射による明かりを消去できる 值として, 目視判読により決定した。結果を四 2 に示 す。 2 值化処理することにより，月の光の反射によっ て薄暗く光る雲が除去され，漁船や都市などの人工的 な光の分布領域が良好に抽出できている事がわかる。

\section{$4.2 \mathrm{OLS} / \mathrm{TIR}$ データによる海面温度の選定}

OLS/TIRのデータ值 D は以下の式により観測輝度 温度 $T_{B}$ に変換できる。

$T_{B}=\frac{D \times(310-190)}{255}+190$

通常, NOAA/AVHRR では熱赤外 2 チャンネルの デー夕を用いて大気補正を行うが，OLSは熱赤外千ャ ンネルを 1 チャンネルしか持たない。そこでまず, OLSデータと同じ日に観測されたNOAA/AVHRR の 2 チャンネルデー夕を用いて大気補正を行い NOAA/AVHRR 海面温度データを作成した。次にこ の海面温度データをトゥルースデータとして OLS/ TIRの観測輝度温度を簡易的に大気補正することに した。なお OLSとNOAA/AVHRRの観測時間には 約 1 時間ほどのずれがあるが，2 時期の海面温度分布 パターンに大きな変化は見られなかった。

NOAA/AVHRR データの大気補正は, 熱赤外域の ch 4 と ch 5 の観測輝度温度を用いる Sprit-Window

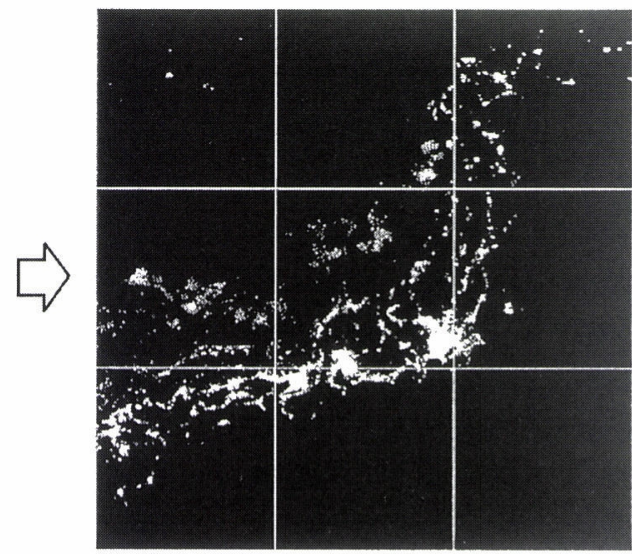

(b) 2 值化後

図 2 OLS/VNIR 画像の 2 值化処理 
法9)を使用して処理を行った。ここで使用した大気補 正式を式 ( 2 )に示す。

$S S T=B \times x 4+C \times x 5+D(x 4-x 5)\{\sec (S Z A)-1\}$

$$
+E
$$

但L,

\section{$S S T$ : 海面温度}

$x 4$ ：千ャンネル 4 の観測輝度温度

$x 5$ ：千ャンネル 5 の観測輝度温度

$S Z A$ : 衛星天頂角

$B=3.457148$

$C=-2.443474$

$D=0.314312$

$E=0.901819$

なおこの日の NOAA の軌道では, 1 周回分のデータ で対象領域全体をカバーすることができなかったた め, 2 周回分の NOAA/AVHRR デー夕を最大值合成 で統合し，対象領域の NOAA/AVHRR 海面温度デ一 夕を作成した。最大值合成したのは，以下の仮定に基 づいている。

1. 雲は海面より温度が低いため, 最大值合成するこ とによって， 2 時期の画像がオ一バーラップして いる領域では雲域の影響が少ないほうのデー夕を 抽出できる。

2. 海流等による海面温度パターンの有意な変化はこ の 2 時期の観測時間（18：13〜19：51）の間には 無い。

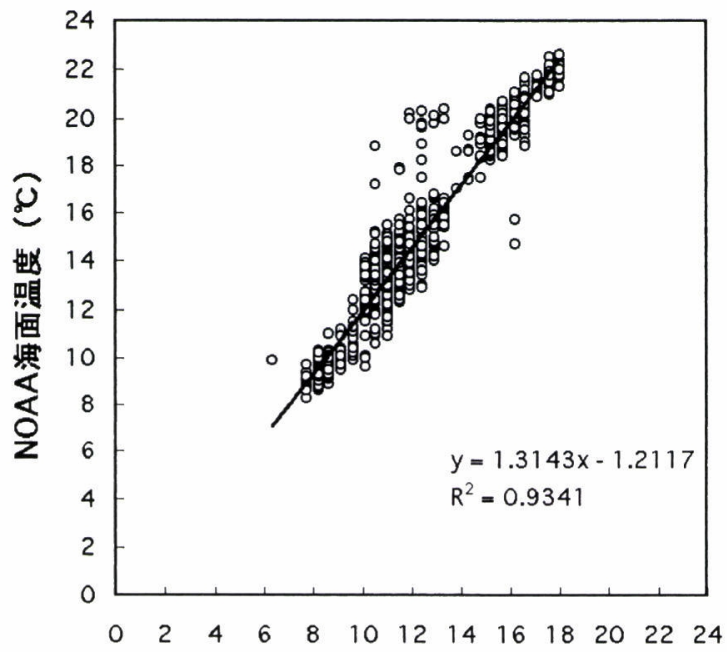

OLS観測輝度温度 $\left(^{\circ} \mathrm{C}\right)$

図 3 OLS 観測輝度温度と NOAA 海面温度の関係

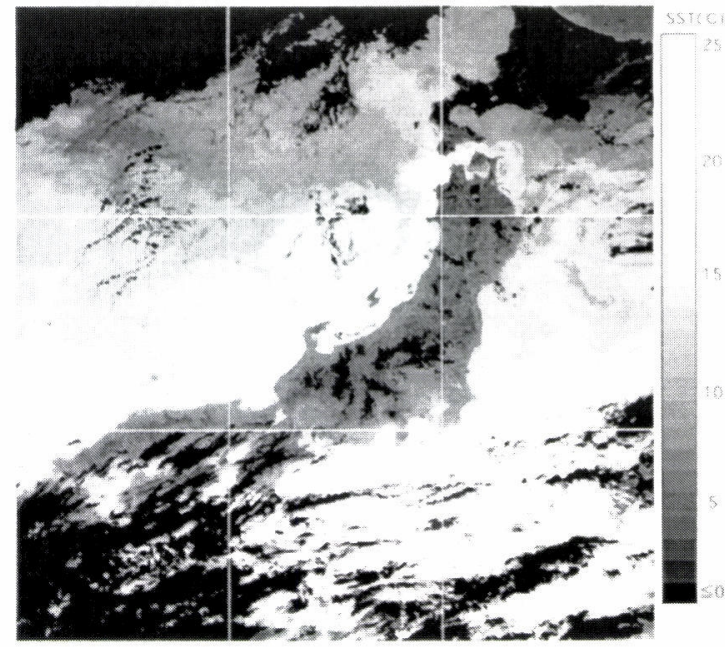

図 4 OLS/TIR 海面温度画像

OLS 観測輝度温度データと NOAA/AVHRR 海面 温度データの比較を行った結果を眓 3 に示す。ここで OLS の観測時間は20：30, NOAA/AVHRRの観測時 間は18：13と19：51である。横軸が OLSの観測輝度 温度, 縦軸が Sprit-Window 法により求めた NOAA/ AVHRR 海面温度である。両者の関係は重相関係数 0.9341 で回帰直線は式 3 のようになった。

$y=1.3143 x-1.2117$

ここで, $y$ は NOAA/AVHRR 海面温度, $x$ が OLS 観 測輝度温度である。

式 (3)を利用し, 各画素ごとに OLS 観測輝度温度 を簡易的に補正して OLS 海面温度を求め, 画像化し た。結果を図 4 に示す。

\section{3 海面温度データとの統合}

ここで，以下のようにして，OLS/VNIR データと OLS 海面温度デー夕の合成を行った。まず，2 值化処 理したOLS/VNIR データの明るい部分に255の值を 与え，それ以外の部分には OLS/TIR データにより推 定した海面温度データの $0{ }^{\circ} \mathrm{C}$ から $25.4^{\circ} \mathrm{C}$ までを $0.1^{\circ} \mathrm{C}$ おきに 0 から 254 までの整数で表現し, 両者の合成画像 の作成を行った。次に合成画像をシュードカラー表示 し，各画素の情報を容易に判別できるようにした。 VNIR データの光の部分には，黄色を割り当てた。ま た, 海面温度デー夕は, 合成したときに光の分布が確 認しやすく，かつ，温度変化が容易にわかるように寒 色系加暖色系に連続的に色を選択し（但し黄色は除 


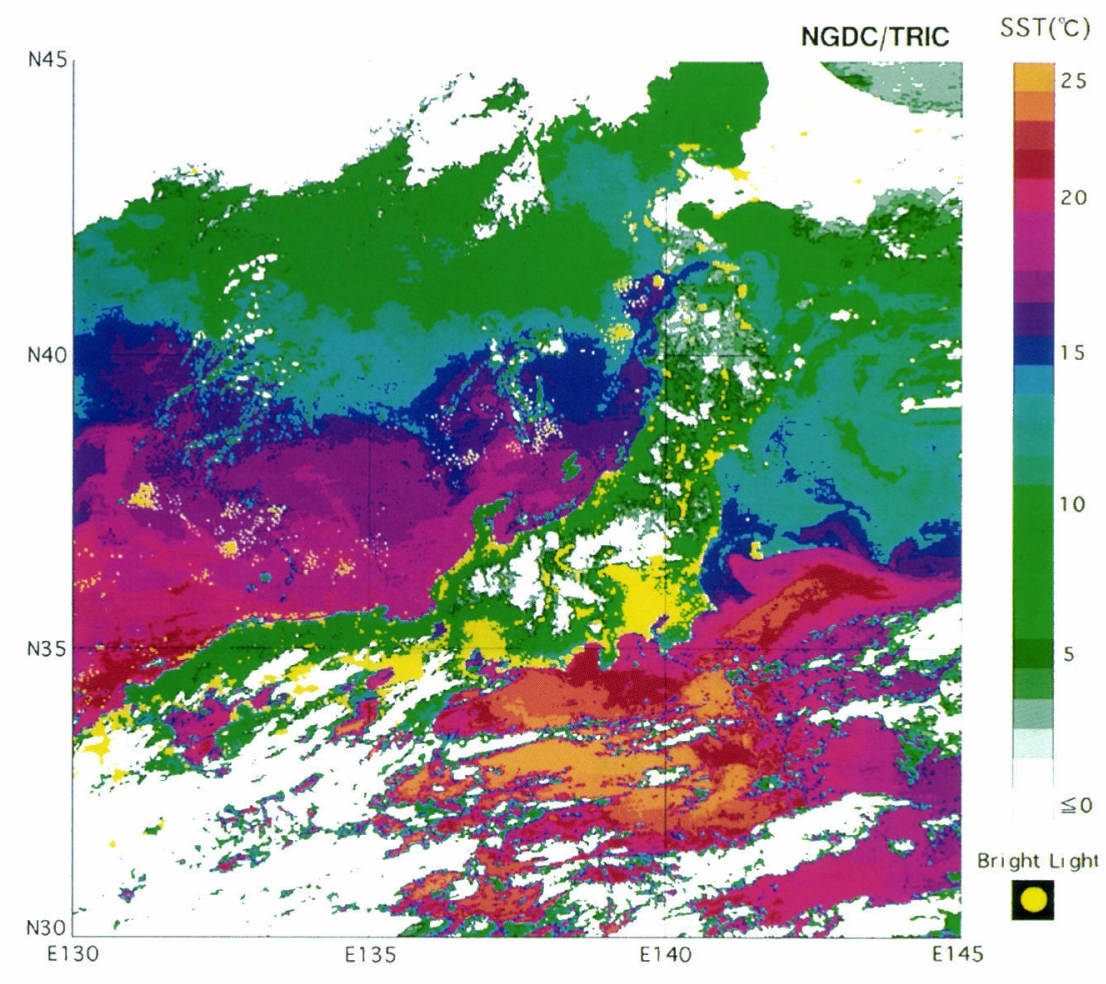

図 5 OLS/VNIR と TIR 合成画像

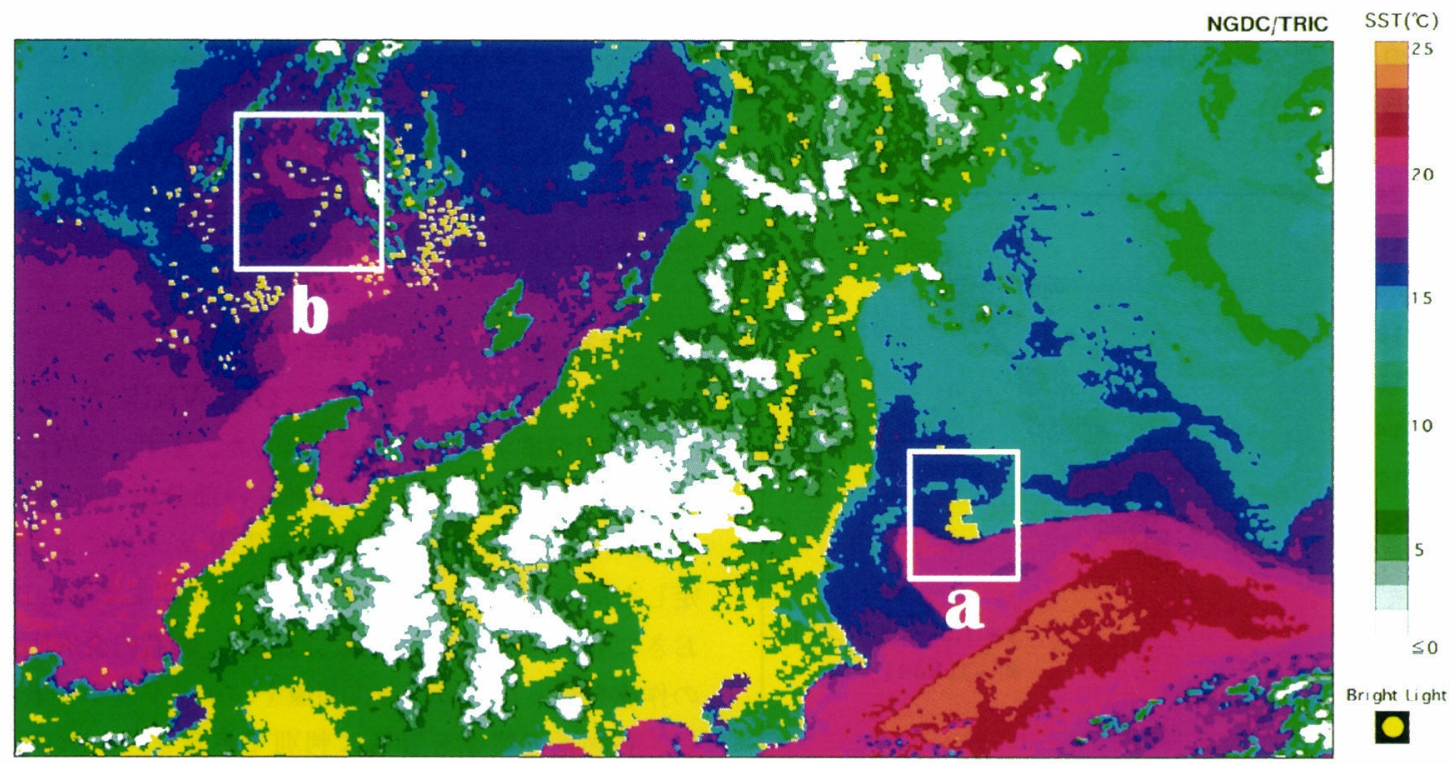

図 6 OLS/VNIR と TIR 合成画像拡大 
外), 連続階調で表示した。結果を図 5 に示す。白〜緑 一青一赤へ変化する連続階調にすることによって, 海 面温度の連続的な変化と海面温度の対応関係の認識が 容易に，かつ光の分布も確認しやすくした。

\subsection{0 海里漁業水域データとの統合}

1994年11月 1 日〜 9 日の 9 日間の OLS 夜間可視画 像から，以下のようにして光の分布域を抽出·合成し， それに領海や200海里の漁業水域を重ね解析した。ま ず， 9 日間で雲の少なかった合計 10 シーンの 2 值化画 像デー夕を加算処理し，11階調の画像を作成した。 1 シーンのみで光の分布が確認された場合, 值は 1 とし, 2 シーンの場合 2,10 シーンの場合で10となっている。 さらに作成した11レベルのデー夕を赤〜黄色の連続階 調でシュードカラー表示し光分布の頻度を色で表現し た。観測日によっては観測されない海域や雲に覆われ た海域がある点は考慮する必要があるが，漁船の出現 頻度を捉える目安にはなる。これに 100 万分の 1 日本周 辺地図，領海と漁業水域の境界線のデー夕と各国の漁 船が海上保安庁に取り締まりを受けた海域のデー夕 (海上保安庁発行の海上保安白書 ${ }^{13)}$ 加抜粋) を合成 し，漁船分布画像を作成した。結果を図10に示す。

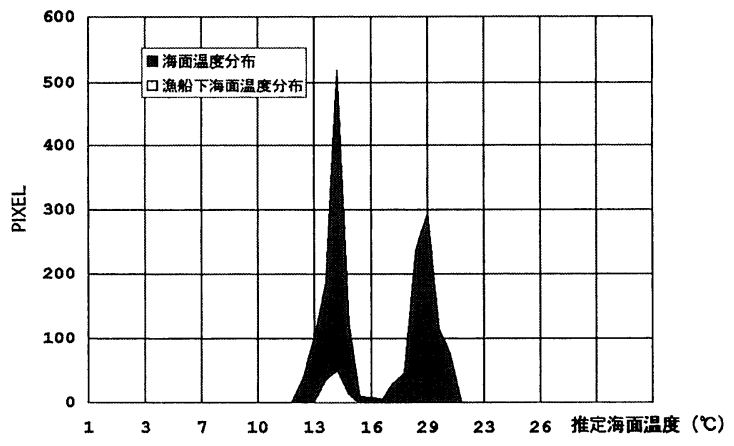

図 7 領域 a の海面温度ヒストグラム

\section{5. 解析結果}

\section{1 合成画像が示す漁場と海面温度の関係}

今回使用した OLS データの観測時期である11月 は，サンマなどが産卵のために南下する時期に対応す る。困 5 を見ると, 親潮域の潮境や日本海側で海面温 度15度付近に漁船が広く分布していることがわかる。 また，画像上では漁船が集中して分布している海域が 多数確認できる。

次に日本北部の海域を拡大した画像を図 6 に示す。 図 6 の $\mathrm{a}$ 海域は銚子沖の海面温度約 $20^{\circ} \mathrm{C}$ の黒潮分流 と約 $15^{\circ} \mathrm{C}$ の親潮の潮境の海域である。この海域では潮

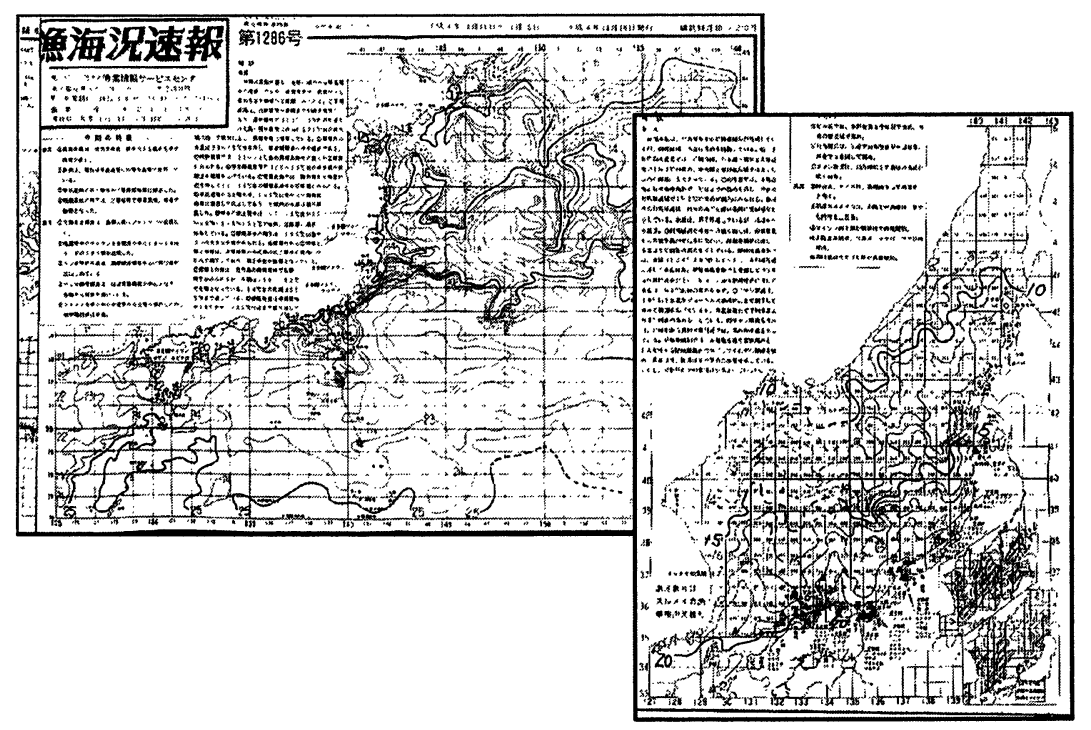

図 8 漁海況情報（1994/11/1 1994/11/15）

＜漁業情報サービスセンター提供 > 


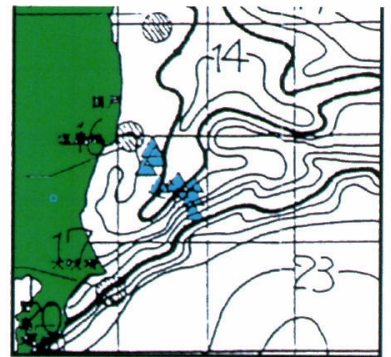

a) 漁海況情報

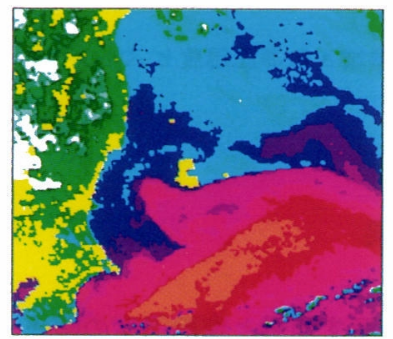

b) OLS 画像

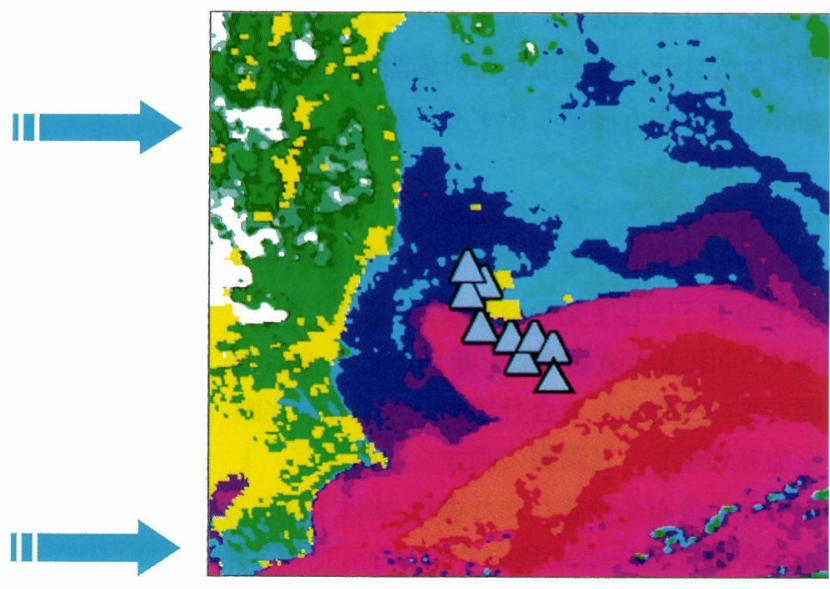

c) 合成画像

図 9 漁海況情報と OLS 画像の合成

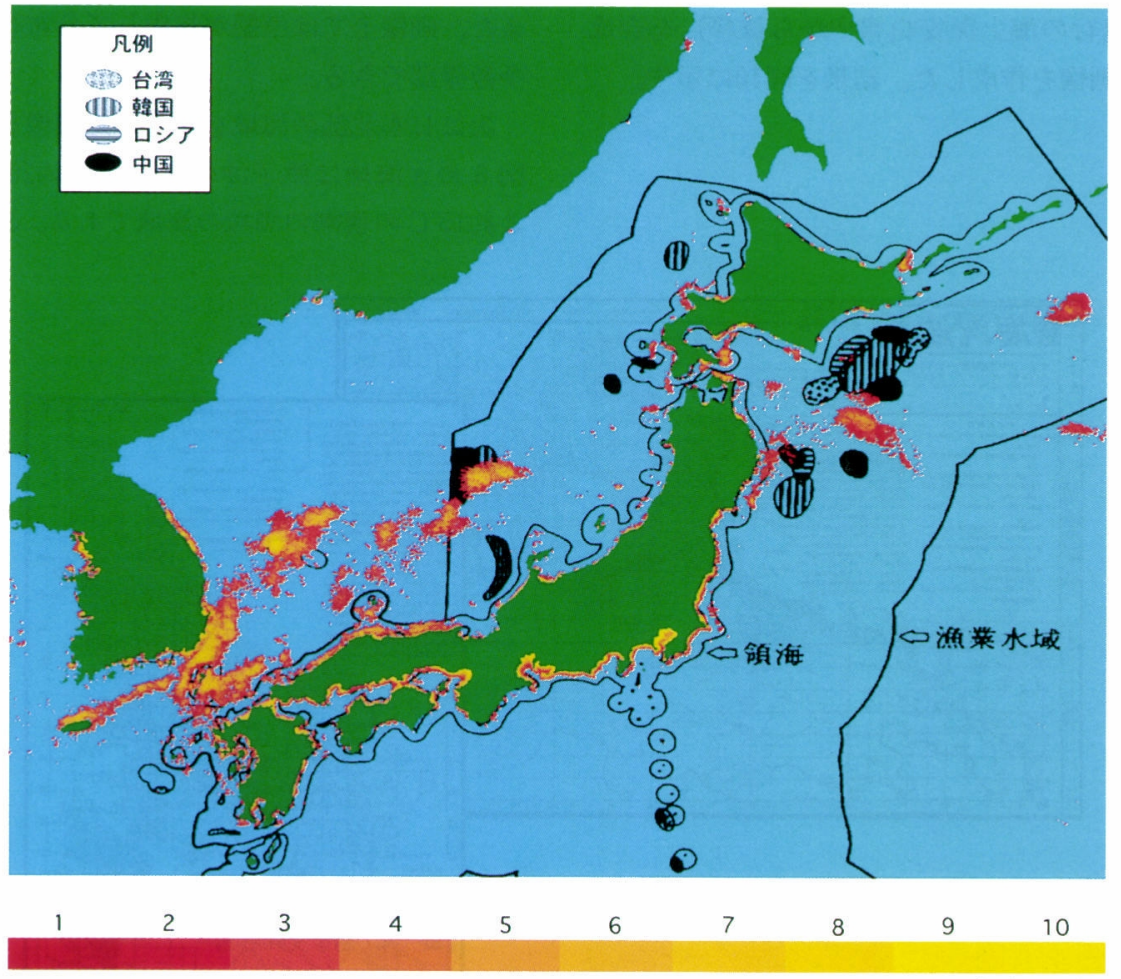

光分布確認回数

1994年11月1日 9日 
境の低温である親潮側に多数の漁船が集中しているこ とが確認できる。この領域のヒストグラムを図 7 に示 す。横軸が推定海面温度, 縦軸が画素数である。黒い グラフがこの領域の海面温度ヒストグラム, 白いグラ フが漁船の明かりが検出された海域の海面温度ヒス卜 グラムである。このグラフからも, 約 $15^{\circ} \mathrm{C}$ を心とし た冷水の親潮側に漁船の光の分布が集中していること が確認できる。つまり, グラフ上で $16^{\circ} \mathrm{C}$ 前後の度数が 少ない事から，扔そらくこの温度付近でフロントが形 成されており，フロントの冷水側の $15^{\circ} \mathrm{C}$ 前後の水温が 幅広くなっているところに漁場が形成されていること を示唆している。日本海側の b 海域では暖水に卷き込 まれた帯状の冷水に沿って漁船が列をなして入り込ん でいる様子を確認することが出来る。図 8 は漁業情報 サービスセンターが週間で発行している太平洋漁海況 速報と日本海漁海況速報であり, 図 6 の OLS デー夕 と同時期ものである。この漁海況情報は, 日本国籍の 各漁船が漁をしている緯度経度を漁業情報サービスセ ンターに無線で報告し，それを同センターで漁船や商 船等から送られてくる表面水温デー夕と NOAA/ AVHRR 海面温度画像より求めた表面温度分布図に プロットしたものである。この漁海況情報にはサン マ・スルメイカ・カツオ等の漁を行った海域が記号で 記されている。当時の漁海況情報に記されている漁場 を図 6 の日本北部拡大画像にプロットしたものを図 9 に示す。当時サンマ棒受網漁船が操業していた位置(三 角印)が OLS で捉之た光の分布と重なった。この海域 の光の分布がサンマ棒受網漁船の操業によるもので, この海域に実際にサンマの漁場が形成されていたこと が確認できた。また, サンマ棒受網漁船と同様に b 海 域ではアカイカ・スルメイカの南下期を捉える漁船の 操業が確認できた。これらの結果は, OLSのVNIR・ TIR デー夕統合利用の有効性を示唆している。

\subsection{0 海里漁業水域と漁場の関係}

海岸の低潮線や湾口等に引かれる直線の集合として 領海法で定められた基線から 12 海里（約 $22 \mathrm{~km}$ ) の水域 を領海と呼び, 基線から 200 海里 (約 $370 \mathrm{~km}$ ) 内の水域 を200海里漁業水域という。日本の周辺海域には好漁場 も多く, 日本の漁船以外にもロシア, 韓国, 中国, 台 湾といった近隣諸国等の漁船が多数操業している。こ のため,「外国人漁業の規制に関する法律」「漁業水域 に関する暫定措置法」等により，200海里漁業水域内等
における正常な漁業秩序の維持や水産資源の適切な保 存及び管理が図られている。しかし，これらの外国漁 船の中には, 自船の水揚げ量を増加させるため, 日本 の漁業水域等において不法操業を行うものが跡を絶た ない。そのため, 海洋生物資源の枯渇等につながる恐 れが懸念され，これらの取り締まりが課題となってい る。

図10の解析結果から，1994年11月に山除沖合いから 九州西岸にかけての西日本周辺海域でスルメイカ漁等 が盛んに行われていたことが推測される。画像からは 光の分布の出現頻度が確認でき, それから良い漁場を 推定することもできる。また，日本海側では漁業水域 の境界域でも漁が盛んに行われ, 中国, 韓国の漁船が 過去に取り締まりを受けている海域でも漁船の光の分 布が捉えられている事がわかる。以上より OLS デー 夕拉よびその統合利用は, 情報量の少ない諸外国の漁 船の分布や操業状況の把握および海洋生物の資源管理 に有効であると考えられる。

\section{6.まとめ}

OLS/VNIR データは夜間に漁を行っている漁船の 光の分布を捉えることができる。本研究では同デー夕 を海面温度分布デー夕と統合利用することにより，広 域にわたる海面温度の分布と夜間に漁を行っている漁 船の光の分布の対応関係を検証した。解析結果は, 潮 境や暖水渦等の周辺に漁場が形成されるというこれま での定説を裏付けた。また, 200 海里漁業水域デー夕と の合成画像は，この水域における漁船の無秩序な操業 状沉をよく捉えていた。OLSデー夕は，漁場形成機構 の解明と情報が少ない諸外国の漁船の分布や操業状況 の把握抒よび海洋生物の資源管理に役立つものと期待 される。

\section{7. 謝辞}

本研究を進めるにあたり, 漁業情報サービスセン 夕一の為石日出生博士, 北海道大学水産学部の斎藤誠 一助教授に資料提供や，貴重なアドバイスをいただい た。またOLSデータの入手, 処理に際しては, NOAA/ NGDCにいろいろ協力いただいた。記して感謝しま す。

(受付日1998.5.11, 受理日1998.7.16) 


\section{参考文献}

1 ）為石日出生, 暖水ストリーマーと漁場の形成, 海 洋科学, Vol. 25, No.2, pp.105 111, 1993

2 ) 為石日出生, 衛星の登場と新しい漁業形成, 日本 リモートセンシング学会誌, Vol. 11, No.2, pp. 126 136, 1993

3 ）為石日出生, 赤外画像から見た渦動の生成・成長 と漁業，空と海，Vol. 8, pp.1 13，1986

4 ）新谷久夫，北部日本海沖合域におけるスルメイカ の特性と漁場形成について, 水産海洋研究会報 21 , pp.44 48, 1972

5 ）奈須，奥谷，小倉，イ力 (その生物から消費まで), 成山堂書店, pp.69 239, 1996

6 ) Colwell R.N 編, Manual of Remote Sensing Second Edition, American Society of Photogrammetry, pp.664-670, 1983

7 ) Woodrufft T., Sullivan, III, A $1 \mathrm{ckm}$ resolution image of the entire night-time Earth based on cloud-free satellite photograph in the $400-1100 \mathrm{~nm}$ band, Int. J. Remote Sensing, vol. 10, No. 1, pp. $1-5,1989$

8 ）中山, 田中, 菅, 「DMSP 全球夜間映像の作成と夜 の光分布に関する地理学的考察」, 日本リモートセン シング学会, Vol.13，No. 4, pp.1-14， 1993
9 ) McClain, E.P., William, W.G., Walton, C.C Comparative Performance of AVHRR-Based Multi-channel Sea Surface Temperature, Journal of Geophysics Research, Vol.90, pp.11587-11601, 1985

10）「米国軍事気象衛星 DMSP 概要」, コンカレント 日本(侏), 1994

11）「高等地図帳」，二宮書店， 1995

12）杉森康広，「海洋のリモートセンシング」，共立出 版, pp.18, 1982

13）大蔵省印刷局, 「海上保安白書」, 海上保安庁, 平 成 7 年度版，pp.105-109，1995

14）伊藤，長，下田，坂田，「OLS 可視·赤外画像に見 られる漁船の分布と海面温度の関係」, 日本写真測量 学会平成 7 年度秋季学術講演会発表論文集, pp. 147-15, 1995

15）伊藤, 長, 下田, 坂田,「データフュージョンによ る海洋現象の解析」, 第 3 回リモートセンシング フォーラム資料集，pp.59-6，1996

16) Cho, K., Ito, R., Shimoda, H., Sakata, T., Fishing Fleet Lights and Sea Surface Temperature Distribution Observed by DMSP/OLS Sensor, International Journal of Remote Sensing, in print, 1998 